\title{
MANAGEMENT OF CHARACTER EDUCATION BASED ON PANCA JIWA IN PONDOK PESANTREN DARUL MUTTAQIEN BOGOR
}

\author{
Odik Sodikin \\ Universitas Islam Nusantara Bandung \\ Email: odiksodikin@gmail.com \\ Ujang Cepi Barlian \\ Universitas Islam Nusantara Bandung \\ Email: ujangcepibarlian@yahoo.co.id \\ Sofyan Sauri \\ Universitas Pendidikan Indonesia Bandung \\ Email: sofyansauri@upi.edu \\ Dadan Nurulhaq \\ Universitas Islam Negeri Sunan Gunung Djati Bandung \\ Email: dadannh@uinsgd.ac.id
}

\begin{abstract}
:
The purpose of this study was to examine how the management of character education based on the five souls at Pondok Pesantren Darul Muttaqien Bogor. The method used in this research is descriptive method which aims to describe and describe the phenomena in the field, namely scientific phenomena. The results showed that the five souls as the foundation for character education in Islamic boarding schools contain five values, including the value of sincerity, simplicity, independence, ukhuwah Islamiyah, and the value of freedom. Where these five values must be practiced as much as possible so that the students become strong and tough Muslim personalities like buildings that have a solid foundation, and for those who can practice them well, it will be easy to meet the future as well as possible.
\end{abstract}

Keywords: Management, Character Education, Panca Jiwa

\section{A. INTRODUCTION}

The issue of character education spreads based on various events that occur that the morale of the nation's children has declined so sharply. This is due partly to the fact that many schools in Indonesia are only places to transfer knowledge, both general knowledge and ethics, and have not yet reached the level of moral and ethical formation. (character building) (Syafe'i, 2017).

Tilaar (2000) argues that there are three things that need to be reviewed in education. First, education cannot be limited to mere schooling. By limiting education as schooling, education is alienated from real life and society is excluded from its responsibility in education. Therefore, the formulation of education and its curriculum which only distinguishes between formal and non-formal education needs to be refined again by placing informal education which will increasingly play an important role in shaping human behavior in an 
open global life. Second, education is not only for developing students' academic intelligence. The development of the entire spectrum of human intelligence both physically and spiritually needs to be given opportunities in a broad and flexible curriculum program, both in formal, non-formal and informal education. Third, education turns out not only to make humans smart but more importantly human beings who are cultured and aware of the nature of the purpose of their creation. In accordance with the opinion of Sindhunata (2000) that the goal of education is not only educated humans but cultured humans (educated and civized human being). Thus, we can formulate the educational process as a humanization process rooted in moral and religious values, which takes place in the personal, family, community and nation, as well as present and future. Education is a concrete step towards achieving complete humanization. Humans are both objects and subjects of education. In other words, education is an activity or action from, by and for humans (Sauri, 2009).

Efforts to shape the character of students who believe in and fear Allah SWT so that they have Islamic characters such as having good morals, being honest, independent, and having a social spirit manifested in the form of Islamic boarding school culture and traditions Cultivating character values that are oriented to the Al-Qur'an and Sunnah which are realized with the targets and goals set by management. Good management will take advantage of management functions and involve all components, including teachers, staff, parents and the community (Nizarani, 2020).

There are several approaches that can be used in the implementation of character education, namely the value planting approach, the moral development approach, the value analysis approach, the value clarification approach, and the learning approach to do. The value planting approach is the right approach used in character education in Indonesia. The implementation of character education can be carried out in an integrated manner in every day, either through classroom learning or outside the classroom, so that it is possible for this activity to be controlled only in the Islamic boarding school. (Ulum, 2018).

The Indonesian government also recognizes that Islamic boarding schools and madrasas are the basis and source of national education so that they must be developed, given guidance and assistance. This authority and development is under the authority of the Ministry of Religion (Sauri, 2017). The government's seriousness in optimizing functions and realizing the aforementioned national education goals, among others, can be seen from the character education policy that has been promulgated since 2013 . Character education is expected to be implemented by all education units in an integrated manner in classroom learning and school culture. The role of character education is not only integrative in the sense of strengthening the intellectual moral of the student subject, but also curative, both personally and socially, that is, it can be a means of curing social diseases (Julistiaty, 2018).

Character literally means his mental or moral quality, moral strength, name or reputation. In view Doni Koesoema Albertus, (2010) Character is associated with temperament which gives it a definition that emphasizes the psychosocial elements associated with education and environmental context. Character is also understood from a behavioral point of view which emphasizes the somatopsychic elements possessed by individuals from birth. Here character is considered the same as personality. Personality is considered as 
a characteristic or characteristic or style or characteristic of a person, which comes from the formations received from his environment, for example the influence of family in childhood and one's birth.

To achieve this goal, pesantren institutions apply character education-based management in the sense that the management of the boarding school institutions empowers and involves all elements in the pesantren to take responsibility for the success of the learning process to achieve goals. The actors are not only Kyai and the ustadz, but all adults in the pesantren, especially Kyai and Ibu Nyai who must listen to their dawns and advice and obey their orders. (Rodliyah, 2014).

Ricky W. Griffin defines management as the process of planning, organizing, coordinating, and controlling resources to achieve goals effectively and efficiently. Effective means that goals can be achieved according to planning, while efficient means that existing tasks are carried out correctly, correctly, organized, and according to schedule. Thus, management is the basic elements that will always be present and embedded in the management process that will be used as a reference by managers in carrying out activities to achieve goals. (Yusup, 2018).

One of the Islamic boarding schools in Indonesia, which is very concerned about the development of youth character and has its own characteristics in educating its students is the Darul Muttaqien Parung Islamic boarding school in Bogor. The success of the Darul Muttaqien Parung Islamic boarding school in Bogor to become one of the leading Islamic boarding schools in West Java did not just happen. He believes that the successful development of character education at the Darul Muttaqien Parung Bogor Islamic Boarding School, which was founded in 1988, cannot be separated from good management.

Sourced from the explanation above, the purpose of this study is to find out about the management of character education at the Daarul Muttaqien Parung Islamic boarding school, Bogor..

\section{B. METHOD}

The research method used in this research is descriptive method which aims to describe and describe the phenomena that exist in the field, namely scientific phenomena. This study examines forms, activities, characteristics, changes, relationships, similarities and differences with other phenomena. When related to descriptive methods in the field of education, it includes describing phenomena related to education such as learning, curriculum implementation, learning approaches and so on (Malihah \& Ihsan, 2020).

\section{RESULT AND DISCUSSION Character Education Management}

The word management comes from English "manage", which means the art of implementing and managing. Management does not yet have an established and universally accepted definition. Mary Parker Follet, for example, defines management as the art of getting work done through other people. This definition means that a manager is in charge of managing and directing others to achieve organizational goals. Ricky W. Griffin 
defines management as a process of planning, organizing, coordinating, and controlling resources to achieve goals effectively and efficiently. Effective means that goals can be achieved in accordance with planning, while efficient means that existing tasks are carried out correctly, organized, and on schedule (Mulyasa, 2006). Thus, management is the basic elements that will always be present and embedded in the management process that will be used as a reference by managers in carrying out activities to achieve goals (Yusup, 2018).

Management by experts is defined in different terms. Among the opinions of Made (1998) which states that "management is the activity of combining educational resources so that they are centered in an effort to achieve predetermined goals". Meanwhile, Sudjana (1998) defines management as a special ability to carry out an activity with other people or through other people in achieving organizational goals. Furthermore, there is another opinion stating that "management is a structuring process involving potential sources both human and non-human in order to achieve goals effectively and efficiently" (Hanafi, 2015).

Basically, there are three focuses in defining management, namely: First, management as an ability or expertise which then becomes the embryo of management as a profession. Management of a science emphasizes attention to managerial skills and abilities which are classified into technical, human and conceptual abilities / skills. Second, management as a process, namely by determining systematic and integrated steps as a management activity. Third, management as an art is reflected in differences in one's style in using or empowering others to achieve goals (Rusmaini, 217).

Based on the above definition, management is a form of cooperation that involves other people to achieve a goal. If detailed, there are three things that are important elements of management, namely: (1) cooperative efforts, (2) involving two or more people, and (3) to achieve predetermined goals. These three elements indicate that management occurs within an organization, not in a single work performed by an individual.

The characters according to the KBBI (large Indonesian dictionary) are character; psychiatric, moral or character traits that distinguish a person from another; character. Whereas in English the character is "character" which comes from Greek Greek "chrassein" and "kharax" which means to carve. Wynne focuses more on character on how to apply the values of kindness in real actions or everyday behavior. So that in his daily life he always acts honestly, politely, and friendly, which is identified as having good character. Likewise, if someone in his daily life acts arrogant, arrogant, likes to lie, he is said to be an individual with bad character. In line with this understanding, the Director General of Islamic Education, Ministry of Religion of the Republic of Indonesia as quoted by Mulyasa (2013) argues that character is the totality of inherent personal characteristics and can be identified in individual behavior that is unique that distinguishes one individual from another. (Sudibyo, 2015).

Ki Hadjar Dewantara as an Indonesian education figure views that character as manners or character. Character is the union of thoughts, feelings, and will or will, which then creates energy. Meanwhile, in the Ministry of National Education, character is the character, character or personality of a person which is formed from the internalization of various virtues, which are believed and used as a basis for point of view, thought, attitude and action. (Sumaryati, 2016).

If traced further, basically character education is to encourage the birth of complete children (insan Kamil). The growth and development of good character will encourage students to grow with the capacity and commitment to do the best things and do everything right and have a life purpose (Syafiuddin, 2017). 
Lickona says "Character consist of operative values, values in action. Character conceived has three interrelated parts; moral knowing, moral feeling, and moral behavior. Good character consist of knowing the good, desiring the good and doing the good-habits of the mind, habits of the hearth and habits of action". The statement can be explained that the character consists of the values of actions. The character that is understood consists of three interrelated components, namely knowing the good, loving or desiring the good, and acting the good. Shaping character is by growing characters that are the habits of mind, heart, and action, which are interrelated between the three (Widiantari, 2017).

Good character education must involve not only aspects of good knowledge (moral knowing), but also moral feeling and good behavior (moral action). Character education aims to develop the ability of students to make good and bad decisions, maintain what is good and realize that goodness in everyday life wholeheartedly. Character education is not just teaching what is right and what is wrong, more than that character education instills habits (habituation), about good things so that students understand (cognitive domain) about what is good and what is bad, able to feel (domain affective), and used to do good (psychomotor domain) (Mulyono, 2016).

Thus character education is a comprehensive effort so that people understand, care, and behave according to basic ethical values. Where the object of character education is values. These values are obtained through the internalization process of what is known, which takes time so that good character is formed in accordance with the values (life values which are the realities that exist in society) that are implanted.

\section{Panca Soul Based Character Education Management at Pondok Pesantren Darul Muttaqien Bogor}

Broadly speaking, according to Bahri Ghozali, current Islamic boarding schools can be divided into three types a) Traditional Islamic Boarding Schools, namely Islamic boarding schools that organize lessons with a traditional approach. The learning of Islamic religious sciences is carried out individually or in groups with a concentration on classical Arabic books, b) Modern Islamic boarding schools, namely Islamic boarding schools that carry out educational activities with a modern approach through formal education, either madrasah or school, but with classical, and c) Comprehensive Islamic Boarding Schools, namely Islamic boarding schools where the education and teaching system is a combination of traditional and modern. This means that in it the education and teaching of the yellow book with the sorogan, bandongan, and wetonan methods is stipulated, but the school system continues to be developed regularly. (Dhuhani, 2018).

The results of an interview with one of the caregivers, that Darul Muttaqien Islamic Boarding School is a Modern Islamic Boarding School located in the Jabon Mekar village area, Parung District, Bogor Regency, West Java. Officially established as a boarding school on July 18, 1988. Since its establishment, from year to year Darul Muttaqien Islamic Boarding School has experienced significant progress both in terms of quality and quantity. Until now, the educational activities developed by Darul Muttaqien Islamic Boarding School include: Islamic Kindergarten, Integrated Islamic Elementary School, Integrated Islamic Junior High School, Tsanawiyah Madrasah, Madrasah Aliyah, Salafiyah Islamic Boarding School, Diniyah Takmiliyah and TPA.

Darul Muttaqien Islamic Boarding School, as stated in the AD / ART of the Darul Muttaqien Foundation, is the core of activities for providing social services for the community with the form of management of educational institutions. The pesantren system as it is commonly known is a 24 hour education system. This means that students (santri) are boarded, so that all student activities for 24 hours are programmed and integrated activities in the supervision and guidance of carer teachers, both formal academic activities at school and dormitory-based non-academic activities. 
All activities are directed to support Darul Muttaqien's educational vision through daily, weekly, monthly and annual activities. The basic spirit that is used as the spirit to carry out educational tasks in Islamic boarding schools is the values of Islamic teachings in general. As specifically stated in the formulation of Pancajiwa Pondok: sincerity, simplicity, independence, ukhuwah Islamiyah and freedom. To achieve the educational goals stated in the vision and mission, Darul Muttaqien is independent: standing above and for all groups. This Islamic institution has a motto of unity in aqidah, tolerance in khilafiyah and congregation in worship.

To achieve Darul Muttaqien's educational vision, each level of education has formulated a specific and measurable vision and mission. As for the vision of Darul Muttaqien Islamic Boarding School "In order to prepare a quality Muslim generation, Darul Muttaqien Islamic Boarding School implements Integrated Islamic Education with a" learning process "approach and communicates in Arabic and English through integrated management and increased partnership relations." There are five indicators of a quality generation, namely: the quality of faith and piety, the quality of knowledge and insight, the quality of character and personality, the quality of life skills, and the quality of learning achievement.

In achieving this vision, Darul Muttaqien Islamic Boarding School takes the following steps: 1) Implementing integrated management 2) Implementing Integrated Islamic Education 3) Using Arabic and English in communicating 4) Developing and increasing cooperation networks 5) Increasing family relations 6 ) Implement a "learning process" that encourages creativity and independence 7) Develop potentials that can be used as a source of funds.

The main programs of Darul Muttaqien Islamic Boarding School include: 1). Implementing Integrated Management, consisting of: Improving the quality of human resources, Perfecting the organizational structure, Increasing work productivity, Creating and implementing a work system that encourages the fulfillment of user satisfaction, Organizing and completing facilities and infrastructure. 2) Implementing Integrated Islamic Education, consisting of: Implementing an Integrated Curriculum, Creating an Islamic atmosphere that can develop harmony in aspects, intellectual, emotional and skills 3). Using Arabic and English in Communication, consists of: Improving the ability to speak Arabic and English and Creating situations that encourage the use of Arabic and English. 4) Developing and Improving Cooperation Relationships (Networking) 5) Improving Family Relations, consisting of: Building a climate that encourages the creation of a family atmosphere. 6) Implementing the Learning Process consists of: Creating an atmosphere that triggers the Learning Process 7) Developing potentials that can be used as a source of funding consisting of: Increasing the potential for raising funds both internally and externally.

The strategy to achieve Darul Muttaqien's vision based on an interview with one of the board members of Darul Muttaqien Islamic Boarding School is divided into nine steps, including: 1) Socializing the improvements that have been determined 2) Forming a team that will create change opinions 3) Designing change programs systematically, systematically and continuously 4) Increasing rewards through the implementation of a merit system 5) Requiring the gradual use of Arabic and English 6) Informing the competitive advantages possessed 7) Taking formal and informal approaches in building cooperation and partnership relationships 8) Performing work efficiency 9) Improve services to users 10) Require each individual to make a contract of change 11). Design changes together.

Darul Muttaqien Islamic Boarding School in Bogor has a principle that students should practice. This principle is commonly referred to as Panca Jiwa Pondok. Panca Jiwa Pondok are the five pillar values that underlie life in the pesantren. These values contain important messages as the spirit of the pesantren to form a strong character of the Islamic generation. Panca Jiwa, among others: 


\section{Sincerity Value}

The meaning of sincerity applied in Darul Muttaqien Islamic Boarding School is based on the values contained in the al-Qur'an, namely as a form of directed effort in obtaining a result by using the purity of his heart as a manifestation of his own glory in order to wish Allah's blessing alone. This value is always recommended by the board of Darul Muttaqien Islamic Boarding School as the basis for all other values. Sincerity implanted has the meaning of being lonely (free from hope other than Allah alone). It means that all activities carried out in Islamic boarding schools are not driven by the desire to obtain certain benefits. All activities are carried out with the sole intention of worship, lillah (intending for the sake of Allah). Kyai as the leader of the pesantren is sincere in educating. Ustadz is sincere in guiding and educating the students. Santri are sincere to be educated and educate themselves, and teachers must also be sincere in helping leaders manage education in the pesantren.

\section{The Value of Simplicity}

Simple is not poverty but rich. Simple not ignorance but smart. Simple is not laziness but sincerity. Simple is not self-humiliation but self-glory. The simple reason is his attitude. Life in the hut is filled with an atmosphere of simplicity. Simple does not mean passive or nerimo (take for granted). In the pattern of behavior of students, teachers and kyai or boarding school leaders Darul Muttaqien are always taught to live simply. The opposite of simple words that are prohibited from being practiced at Darul Muttaqien Islamic Boarding School is to live extravagantly and with luxury. According to the rules of the Darul Muttaqien Islamic Boarding School, they are not allowed to bring various unnecessary jewelery or bring too much pocket money because it will be wasteful. Wasteful attitude means doing something that is not in accordance with the needs or exceeds the needs that should be. Extravagant attitude means fulfilling something according to desire and desire alone. This value is what is meant by simplicity in the five souls of the cottage.

\section{Value of Independence}

The definition of independence carried out at Darul Muttaqien Islamic Boarding School is the ability to help itself not only in the sense that students are able to take care of their own interests, but that the Islamic boarding school itself as an educational institution must also be able to be independent. So that both students and institutions do not rely on the help and mercy of other parties. At Darul Muttaqien, the leadership always developed that chickens could be independent to find food every day, especially for human beings. Santri cannot lose to chickens. The independence of the pesantren as an educational institution needs no question. This is because the pesantren has been independent since its establishment in colonial times with the funds of the kyai and the community. Pesantren have never relied on various assistance from the government, if given it differently. Even in the course of its history, the establishment of pesantren was very isolated by the government and was suspected by the colonial nation. It is not surprising that many of the kyai, ulama and santri at that time were victims and killed by the invaders and traitors of Islam..

\section{Ukhuwah value}

Life activities at Darul Muttaqien Islamic Boarding School are always surrounded by a close brotherly atmosphere. This value is reflected in Darul Muttaqien Islamic Boarding School with the term principle of kinship. All joys and sorrows are felt in the brotherhood of fellow Muslims. Because of that, the leadership always said in every speech in the term Darul Muutaqien family. So substantially all residents of Darul Muttaqien, both students, teachers and workers, are considered to be Darul Muttaqien's extended family. 
This value is evidenced by various events and programs as well as behavior. All teachers' children by the leadership are all our children, so all teachers must pay attention and remind the teacher's children if they do something bad. Darul Muttaqien Islamic Boarding School does not allow teachers to distinguish between children, all must be considered. Kinship values are also practiced in worship, mutual respect, mutual respect for fellow teachers, and unity in belief. So this value is reflected in Darul Muttaqien's famous slogan: unity in aqidah, congregation in worship, and tolerance in khilafiyah. Family values are also realized in a work atmosphere that prioritizes team work over individual work.

\section{Value of Freedom}

Freedom means the freedom to create and take a fighting role according to one's capacity, without any pressure and coercion from anyone. The decision to take the role of struggle is based on devotion to Allah alone, with the intention of worship. The freedom to develop oneself towards a quality person is wide open in this institution. It remains every single person to be able to take every opportunity for good and meaningful. Freedom in thinking and doing, free in determining the future, free in choosing the path of life, and even free from various negative influences from outside. This value of freedom should not be misused to become too free (liberal) so that it loses direction and purpose or principle. Therefore, the value of this freedom must be returned to its original state, namely freedom in positive disciplinary lines, with full responsibility, both in the life of the boarding school itself, and in community life. This freedom must always be based on true teachings based on the scriptures and sunnah. In other words, the freedom to work and do positive things based on talents and interests and not to leave the corridor of Islamic teachings. This value is applied in Darul Muttaqien to teachers, by being given the freedom to develop themselves, develop creativity and innovation in teaching, freedom to choose their way of life whether they still want to exist in Darul Muttaqien or develop themselves outside campus, freedom to work and so on during all of that. still in the corridor of Islamic teachings. This value of freedom is also enforced among the students in kindness or in positive ways. Santri are given the freedom to develop themselves according to their talents, freedom to express themselves through art and works, freedom to make choices after completing Darul Muttaqien, freedom to choose the preferred major, freedom to choose extracurricular programs provided at the institution. All forms of freedom must be under the guidance of the supervising teachers. And more importantly, all the freedoms that are developed are positive ones based on Islamic teachings.

These five values are certainly familiar to the members of the Darul Muttaqien Islamic boarding school community. However, there are also many students, especially those who are new, who do not know this basic value. But over time, they must understand and be able to live these values. Pondok not only teaches scientific issues of general studies or Islamic studies, more than that, Pondok also teaches the values of life that are contained in the Panca Jiwa Pondok. Of course, through all kinds of applications in every activity that goes on in the cottage. Therefore, without realizing it, this gradually implanted and formed in each santri. KH. Mad Rodja Sukarta, as the leader of the Darul Muttaqien Islamic boarding school in Bogor, advised that the Panca Jiwa Pondok should be practiced as much as possible so that the students will become strong and tough Muslim personalities like buildings with solid foundations; so that when they are involved in social life, they can apply these five principles. For those who can practice it well, it will be easy to meet the future as well as possible.

\section{CONCLUSION}

Based on the above discussion, it can be concluded that the management of character education based on the five souls at Pondok Pesantren Darul Muttaqien Bogor is through the values of sincerity, simplicity, 
independence, ukhuwah Islamiyah, and freedom. Where as the spirit of the pesantren, these five values must be practiced as much as possible so that the students become strong and tough Muslim personalities like buildings that have a solid foundation; so that when they are already involved in social life, they can apply these five principles, and for those who can practice them well, it will also be easy to meet the future as well as possible.

\section{References}

Dhuhani, E. M. (2018). Manajemen Pondok Pesantren; Studi Pengelolaan Santri Muallaf di Pondok Pesantren Al Anshar Ambon. Jurnal Fikratuna, 9(1), 54-70.

Doni Koesoema Albertus. (2010). Pendidikan Karakter; Strategi Mendidik Anak di Zaman Global. Grasindo. Hanafi. (2015). Manajemen Pendidikan Karakter Siswa di Sekolah Dasar. Manajer Pendidikan, 9(5), 629_ 637.

Julistiaty, dkk. (2018). Manajemen Pendidikan Karakter dalam Membentuk Karakter Siswa SMP Tunas Bangsa Sunter. Jurnal Akuntabilitas Manajemen Pendidikan, 6(2), 241-251.

Malihah, I., \& Ihsan, M. N. (2020). Pengembangan Metode Market Place dalam Pembelajaran PAI. Atthulab: Islamic Religion Teaching and Learning Journal, 5(1), 56-70. https://doi.org/10.15575/ath.v5i1.8193

Mulyono. (2016). Nilai-Nilai Pembentuk Karakter dalam Filsafat Sosrokartono. Sabda, 11(2), 41.

Nizarani, dkk. (2020). Manajemen Pendidikan Karakter Berbasis Pondok Pesantren. Jurnal Intelektualita: Keislaman, Sosial, Dan Sains, 9(1), 37-44.

Rodliyah, S. (2014). Manajemen Pondok Pesantren Berbasis Pendidikan Karakter. Jurnal Cendekia, 12(2), 299-314.

Rusmaini. (217 C.E.). Manajemen Pendidikan Karakter di Lembaga Pendidikan Islam. Journal of Islamic Education Management, 3(1), 132-147.

Sauri, S. (2017). Nilai Kearifan Pesantren (Mohamad Zaka Al-Farisi (ed.)). Rizqi Press.

Sofyan Sauri. (2009). Masalah-Masalah Pokok Pendidikan di Indonesia dalam Perspektif Filosofis, Teoretik dan Empirik. Seminar Nasional Bagi Guru-Guru Di Kabupaten Subang.

Sudibyo, P. (2015). Manajemen Pendidikan Karakter di Taman Kanak-Kanak Bias Palagan Yogyakarta. Jurnal El-Tarbawi, VIII(2), 195-206.

Sumaryati. (2016). Manajemen Pendidikan Karakter. Jurnal Tarbawiyah, 13(2), 205-220.

Syafe'i, I. (2017). Pondok Pesantren: Lembaga Pendidikan Pembentukan Karakter. Al-Tadzkiyyah: Jurnal Pendidikan Islam, 8(1), 61. https://doi.org/10.24042/atjpi.v8i1.2097

Syafiuddin, M. (2017). Pendidikan Karakter Dalam Perspektif Filsafat Pancasila (Issue 1) [UIN Raden Intan lampung]. https://doi.org/10.1017/CBO9781107415324.004

Ulum, M. (2018). Pembentukan Karakter Siswa Melalui Pendidikan Berbasis Pondok Pesantren. Jurnal Evaluasi, 2(2), 382-397.

Widiantari, D. (2017). Core Ethical Values Pendidikan Karakter (Berbasis Falsafah Negara). MISYKAT: Jurnal IImu-IImu Al-Quran, Hadist, Syari'ah Dan Tarbiyah, 2(2), 21-38. http://pps.iiq.ac.id/jurnal/index.php/MISYKAT/article/view/3

Yusup, M. (2018). Manajemen Pendidikan Karakter Berbasis pondok Pesantren Darussyifa Al-Fithroh Yaspida Sukabumi. Jurnal Tadbir Muwahhid, 2(April), 11-24. 